\title{
DEVELOPMENT OF BIOLOGICAL ASSESSMENT BASED ON SCIENCE PROCESS SKILLS IN SENIOR HIGH SCHOOL CITY OF PALEMBANG
}

\author{
Linda Aprianingsih, Sri Wardhani, Sulton Nawawi* \\ Progam Studi Pendidikan Biologi, Universitas Muhammadiyah Palembang. \\ Jalan Jenderal Ahmad Yani, 13 Ulu, Seberang Ulu II, Kota Palembang, 30116, Indonesia \\ *sulton.bio@gmail.com
}

Doi: 10.31943/mangiferaedu.v6i1.122

Received: November 17, 2020 Accepted: May 16, $2021 \quad$ Published: July 31, 2021 Citation: Aprianingsih, L., Wardhani, S., Nawawi, S., (2021). Development of Biological Assessment Based on Science Process Skills in Senior High School City of Palembang. Jurnal Mangifera Edu, 6(1), 82-97.

\begin{abstract}
The research background is that it can develop biological assessment based on science process skills because science process skills are important for logical thinking to train students' thinking skills. From the results of the initial needs analysis of class $X$ questions, science process skills are still low, the teacher has not fully developed the science process skills-based assessment because it still uses questions from biology books. This study aims to determine the characteristics and feasibility of assessment based on science process skills developed in biology class $X$ semester 2. This research is a development research. Development is carried out using a procedural model by adapting Mcintire's research and development model, with 4 stages of test development including defining competencies, test participants and test objectives, developing test plans, compiling test items, writing administrative instructions. This research stage is limited because it only wants to know the characteristics and feasibility of the assessment. The research instrument used an interview sheet, a questionnaire sheet and an observation sheet. Expert validation was carried out by 6 expert validators: (1) material experts; (2) linguist; and (3) evaluation experts; The data analysis technique uses qualitative descriptive that refer to the formula adapted by Sugiyono (2018) with a scale of 4. The results of this study are in the form of a biological assessment based on science process skills in the form of multiple choice questions in which there is biology material for class $X$ semester 2.Biological assessment characteristics based on science process skills, namely using indicators consisting of observing, grouping, interpreting, predicting, asking questions, hypothesizing, planning experiments, applying concepts and communicating. The feasibility of a biological assessment based on science process skills based on expert validators, the results are valid to very valid so that the biological assessment based on science process skills developed is feasible to be used to measure the science process skills of class $X$ students.
\end{abstract}

Keywords: Assessment, Biology, Science process skills, Even semester.

\section{ABSTRAK}

Latar belakang penelitian yaitu dapat mengembangkan asesmen biologi berbasis keterampilan proses sains karena keterampilan proses sains penting bagi berpikir logis untuk melatih kemampuan berpikir peserta didik. Hasil analisis kebutuhan awal soal kelas 
Jurnal Mangifera Edu, Volume 6, Issue 1, July 2021, 82-97

X keterampilan proses sains masih rendah guru belum sepenuhnya mengembangkan asesmen berbasis keterampilan proses sains karena masih menggunakan soal dari buku biologi. Penelitian ini bertujuan untuk mengetahui karakteristik dan kelayakan asesmen berbasis keterampilan proses sains yang dikembangkan pada materi biologi kelas $X$ semester 2. Penelitian ini merupakan penelitian pengembangan. Pengembangan yang dilakukan menggunakan model prosedural dengan mengadaptasi model penelitian dan pengembangan Mcintire, dengan 4 tahapan pengembangan tes meliputi mendefinisikan kompetensi, peserta tes dan tujuan tes, mengembangkan rencana uji, menyusun item tes, menulis instruksi administrasi. Tahap penelitian ini dibatasi karena hanya ingin mengetahui karakteristik dan kelayakan asesmen. Instrumen penelitian menggunakan lembar wawancara, lembar kuesioner dan lembar observasi. Validasi ahli dilakukan oleh 6 validator ahli: (1) ahli materi; (2) ahli bahasa; dan (3) ahli evaluasi; Teknik analisis data menggunakan teknik deskriptif kualitatif yang mengacu pada rumus yang diadaptasi oleh Sugiyono (2018) dengan skala 4. Hasil penelitian ini berupa asesmen biologi berbasis keterampilan proses sains berbentuk soal pilihan ganda yang di dalamnya terdapat materi biologi kelas X semester 2. Karakteristik asesmen biologi berbasis keterampilan proses sains yaitu menggunakan indikator terdiri atas mengamati, mengelompokkan, menafsirkan, meramalkan, mengajukan pertanyaan, berhipotesis, merencanakan percobaan, menerapkan konsep dan berkomunikasi. Kelayakan asesmen biologi berbasis keterampilan proses sains berdasarkan validator ahli hasilnya berkualifikasi valid sampai dengan sangat valid sehingga asesmen biologi berbasis keterampilan proses sains yang dikembangkan layak untuk digunakan untuk mengukur keterampilan proses sains peserta didik kelas $X$.

Kata Kunci: Asesmen, Keterampilan proses sains, Biologi, Semester genap.

\section{PENDAHULUAN}

Pendidikan merupakan aspek terpenting didalam kehidupan manusia. pendidikan sebagai wadah untuk membentuk karakter seseorang, potensi diri dan pola pikir seseorang yang dapat ditingkatkan melalui proses pembelajaran. Pendidikan dapat diperoleh dan dikembangkan melalui sekolah, keluarga, dan masyarakat, sehingga menghasilkan karakter peserta didik yang berkualitas (Aseptianova et al., 2019).

Pendidikan abad ke-21 ditandai sebagai abad keterbukaan atau abad globalisasi, artinya kehidupan manusia pada abad ke-21 mengalami perubahan-perubahan yang fundamental yang berbeda dengan tata kehidupan dalam abad sebelumnya. Abad 21 memiliki banyak perbedaan dengan abad 20 dalam berbagai hal, diantaranya dalam pekerjaan, hidup bermasyarakat dan aktualisasi diri. Abad 21 ditandai dengan berkembangnya teknologi informasi yang sangat pesat serta perkembangan otomasi dimana banyak pekerjaan yang sifatnya pekerjaan rutin dan berulang-ulang mulai digantikan oleh mesin, baik mesin produksi maupun komputer (Wijaya et al., 2016). 
Salah satu kemampuan abad 21 yang harus dikuasai yaitu critikal thinking skiil. Pendidikan di abad 21 dapat membawa kita pada perubahan paradigma yang dramatis, dari masyarakat industri kemasyarakat ilmu atau masyarakat belajar. Keterampilan abad 21 setiap orang harus mengajarkan 4 kompetensi yaitu communication, collaboration, critical thinking dan creativity (Husnita et al., 2019).

Tuntutan perubahan mindset manusia abad 21 menuntut pula suatu perubahan yang sangat besar dalam pendidikan nasional, yang kita ketahui pendidikan kita adalah warisan dari sistem pendidikan lama yang isinya menghafal fakta tanpa makna. Pembelajaran di abad 21 yang menuntut peserta didik untuk memiliki keterampilan pengetahuan dan kemampuan dibidang teknologi, media dan informasi, keterampilan pembelajaran dan inovasi serta keterampilan hidup dan karir (Wijaya et al., 2016). Salah satu jenis keterampilan yang perlu di kembangkan dari aktivitas pembelajaran adalah keterampilan proses sains.

Keterampilan proses sains merupakan seperangkat keterampilan yang digunakan para ilmuan dalam melakukan penyelidikan ilmiah. Keterampilan proses sains ini dibedakan menjadi sejumlah keterampilan proses yang perlu dikuasai bila seseorang hendak mengembangkan pengetahuan sains dan metodenya (Rustaman et al., 2012). Keterampilan proses sains bisa dinilai atau diukur menggunakan instrumen pengukuran berupa asesmen. Asesmen merupakan prosedur yang digunakan untuk mendapatkan informasi untuk mengetahui taraf pengetahuan dan keterampilan peserta didik yang hasinya akan digunakan untuk keperluan evaluasi (Subali, 2012). Selain itu tugas pendidik adalah mampu mengembangkan keterampilan-keterampilan yang dimiliki oleh siswa, salah satunya adalah keterampilan proses sains. Untuk melatih keterampilan berpikir siswa dengan menggunakan soal-soal berbasis keterampilan proses sains.

Berdasarkan hal tersebut, maka proses asesmen atau penilaian tidak dapat dipisahkan dalam proses pembelajaran. Tujuan penilaian atau asesmen diantaranya adalah untuk mengetahui tingkat ketercapaian dari tujuan pembelajaran, melihat keefektifan proses belajar mengajar, dan untuk mengetahui seberapa besar tujuan dapat dicapai (Wijayanti, 2014).

Asesmen pendidikan dapat pula dimanfaatkan untuk mengetahui kesesuaian antara yang didapat peserta didik kapasitas peserta didik yang bersangkutan. Asesmen akan menunjukkan apakah peserta didik yang mengikuti kegiatan pendidikan telah mewujudkan dirinya secara optimal sesuai dengan kemampuan yang dimilikinya atau masih jauh dari 
yang diharapkan. Jadi asesmen bermanfaat dalam penempatan peserta didik sesuai latar belakang, keadaan serta keinginannya, sehingga akan membantu dalam proses belajar (Yusuf, 2015).

Penelitian ini dilakukan di empat sekolah di wilayah Seberang Ulu 1 dan Seberang Ulu II yang terdiri dari 4 sekolah yaitu: SMA Negeri 19 Palembang, SMA Negeri 8 Palembang, SMA PGRI 2 Palembang, dan SMA Sriguna Palembang. Dari hasil analisis kebutuhan awal dengan menggunakan lembar observasi, wawancara, dan kuesioner pada guru biologi dan peserta didik kelas $\mathrm{X}$ di 4 SMA tersebut, dalam proses pembelajaran biologi kelas $\mathrm{X}$ sudah menerapkan keterampilan proses sains dalam proses pembelajarannya, namun guru belum sepenuhnya mengembangkan asesmen berbasis keterampilan proses sains karena masih mengambil soal-soal dari buku-buku biologi belum mengembangkan soal-soal berbasis keterampilan proses sains yang sesuai dengan indikator-indikator yang terdapat pada keterampilan proses sains. penilaian yang digunakan oleh guru juga masih mengacu pada aspek kognitif. Pada penilaian aspek kognitif guru menggunakan instrumen penilaian berbentuk tes berupa pilihan ganda dan esay yang ada pada buku biologi sebagai sumber belajar.

Terkait hasil analisis soal di SMA wilayah seberang Ulu I dan Seberang Ulu II Kota Palembang bahwa soa keterampilan proses sains masih rendah, diperoleh hasil yaitu 29,35\% soal yang telah memberdayakan keterampilan proses sains terdiri dari $6,32 \%$ soal yang mencantumkan indikator mengamati dengan kategori kurang, 18,02\% soal yang mencantumkan indikator klasifikasi dengan kategori kurang, 3,75\% soal yang mencantumkan indikator meramalkan dengan kategori kurang dan 2,50\% soal yang mencantumkan indikator merencanakan percobaan dengan kategori kurang. Sehingga asesmen berbasis keterampilan proses sains yang dikembangkan dibutuhkan di SMA tersebut.

Berdasarkan masalah dan fakta di atas, untuk mengukur keterampilan proses sains (KPS) peserta didik pada materi kelas X semester 2, produk yang dikembangkan berupa soal pilihan ganda berbasis keterampilan proses sains pada materi semester genap maka perlu dikembangkan instrumen asesmen yang dapat mengukur keterampilan proses sains peserta didik oleh karena itu dilakukan penelitian pendidikan Biologi di SMA Negeri 19, SMA PGRI 2 Palembang, SMA Negeri 8 Palembang, SMA Sriguna Palembang. 
Jurnal Mangifera Edu, Volume 6, Issue 1, July 2021, 82-97

\section{METODOLOGI PENELITIAN}

Penelitian ini adalah penelitian pengembangan atau Development Research. Penelitian pengembangan ini termasuk dalam jenis penelitian metode deskriptif Kualitatif. Produk yang dikembangkan adalah asesmen berbasis keterampilan proses sains. Pengembangan yang dilakukan menggunakan model prosedural dengan mengadaptasi model penelitian pengembangan (McIntire dalam Mulyatiningsih, 2012). Bertujuan untuk menguji kelayakan asesmen biologi berbasis keterampilan proses sains di SMA Kota Palembang pada semester genap.

Langkah-langkah pengembangan soal berbasis keterampilan proses sains terdapat 10 tahap, tetapi hanya digunakan 1-4 tahapan. Pembatasan langkah pengembangan dilakukan karena tujuan penelitian ini karena hanya ingin dari instrumen yang dibuat. Maka penelitian hanya menggunakan 4 tahap pengembangan model Mcintire yaitu mendefinisikan kompetensi, peserta tes, dan tujuan tes, mengembangkan rencana uji, menyusun item tes dan menulis instruksi administrasi. Kompetensi Dasar yang digunakan meliputi Kompetensi Dasar (KD) materi Biologi kelas X semester 2 dari Permendikbud No. 24 Tahun 2016. Kompetensi Dasar yang digunakan pada penelitian ini dimulai dari KD 3.7 sampai KD 3.11 digunakan sebagai penentu materi yang digunakan untuk membuat asesmen yang dikaitkan dengan indikator keterampilan proses sains.

Populasi dalam penelitian pengembangan asesmen ini adalah peserta didik kelas $\mathrm{X}$ di SMA Negeri 19 Palembang terdiri dari 5 kelas, peserta didik kelas X di SMA Negeri 8 Palembang terdiri dari 5 kelas, peserta didik kelas X di SMA PGRI 2 Palembang terdiri dari 5 kelas dan peserta didik kelas $\mathrm{X}$ di SMA Sriguna Palembang terdiri dari 3 kelas jumlah kesuluruhan 648 peserta didik. Masing-masing sekolah dipilih kelas IPA I. sampel dilakukan dengan sistem kuota sampling yang ditentukan berdasarkan pemilihan jumlah kelas dengan masing-masing sekolah 1 kelas yang terdiri dari 36 peserta didik.

Langkah kedua yaitu mengembangkan rencana uji (Developing a test plan). Meliputi pembuatan kisi-kisi, format pertanyaan atau jawaban, bentuk penyelenggaraan dan cara penskorannya. Kisi-kisi dibuat dari Kompetensi Dasar (KD) materi Biologi kelas X semester 2 dari permendikbud No. 24 Tahun 2016. Materi dikaitkan dengan indikator keterampilan proses sains. Sembilan indikator keterampilan proses sains yang digunakan yaitu mengamati, klasifikasi, menafsirkan, meramalkan, mengajukan pertanyaan, berhipotesis, 
merencanakan percobaan, menerapkan konsep, berkomunikasi. Instrumen test berupa soal pilihan ganda dengan lima pilihan jawaban.

Langkah ketiga menyusun item tes (Composing the test items). Soal yang akan dikembangkan berjumlah 50 butir soal pilihan ganda. Tahap selanjutnya yaitu validasi ahli (expert judgment), validasi dilakukan oleh 3 validator ahli; (1) ahli materi; (2) ahli bahasa; dan (3) ahli evaluasi. Validasi digunakan untuk menguji aspek materi, aspek bahasa dan aspek evaluasi. Isntrumen lembar validasi yang digunakan berupa angket, yang mencakup aspek materi, aspek bahasa dan aspek evaluasi. Pedoman penskoran dapat dilihat pada tabel 1.

Tabel 1. Pedoman pens koran pada angket (Skala Likert)

\begin{tabular}{ccc}
\hline No. & Analisis Kuantitatif & Skor \\
\hline 1. & Sangat Baik & 4 \\
2. & Baik & 3 \\
3. & Tidak Baik & 2 \\
4. & Sangat Tidak baik & 1 \\
\hline \multicolumn{2}{c}{ Sumber: (Sugiyono, 2018) }
\end{tabular}

Menghitung persentase jawaban dari setiap pernyataan pada instrumen validasi dan angket dengan menggunakan rumus sebagai berikut:

Persentase Jawaban Responden=

$$
\begin{aligned}
& \frac{\text { jumlah skor yang diperoleh }}{\text { jumlah skor tertinggi }} \times 100 \\
& \text { Sumber: (Sugiyono, 2018) }
\end{aligned}
$$

Persentase kelayakan yang didapatkan kemudian diinterpretasikan kedalam kategori berdasarkan Tabel 2 .

Tabel 2. Pengambilan keputusan angket validasi

\begin{tabular}{cc}
\hline Tingkat Pencapaian & Kategori \\
\hline$>81,25 \%-100 \%$ & Sangat Valid \\
$>62,5 \%-81,25 \%$ & Valid \\
$>43,75 \% \%-62,5 \%$ & Tidak Valid \\
$25 \%-43,75 \%$ & Sangat Tidak Valid \\
\hline & Sumber: (Riduwan, 2015)
\end{tabular}


Tafsiran hasil validasi ini digunakan untuk menentukan kevalidan (kelayakan) instrumen asesmen yang dikembangkan. Asesmen dinyatakan layak secara teoritis apabila persentase kelayakannya adalah $62,5 \%$.

Langkah keempat yaitu menulis instruksi admistrasi (Writing the adminstration instructions). Langkah ini disusun petunjuk penyelenggaraan tes yang terdiri dari petunjuk untuk penyelenggara, pengawas ujian dan petunjuk untuk peserta tes itu sendiri. Petunjuk penyelenggaraan yang digunakan dalam penelitian ini berisikan kondisi yang harus disiapkan pada saat tes dilaksanakan.

Teknik pengumpulan data yang digunakan yaitu menggunakan wawancara, observasi, angket (kuesioner), dan dokumentasi. wawancara dilakukan dengan melakukan tanya jawab kepada guru dan peserta didik pada saat pengambilan data awal, data tersebut akan dicatat secara lengkap agar diperoleh data yang benar serta menggunakan beberapa pertanyaan yang diajukan dikaitkan dengan indikator keterampilan proses sains. Observasi yang dilakukan merupakan observasi langsung pada saat analisis kebutuhan awal, observasi dilakukan pada saat proses pembelajaran berlangsung di dalam kelas dengan menggunakan beberapa pernyataan sesuai dengan indikator keterampilan proses sains.

Angket digunakan pada saat analisis kebutuhan awal, diberikan kepada guru dan peserta didik dengan menggunakan beberapa pertanyaan sesuai dengan indikator keterampilan proses sains. Dokumentasi berupa tulisan, gambar, atau karya-karya monumental dari seseorang. Dokumen yang berbentuk tulisan misalnya catatan harian, sejarah kehidupan (life histories), cerita, biografi, peraturan, kebijakan. Dokumen yang berbentuk gambar, misalnya foto, gambar hidup, sketsa dan lain-lain. Dokumen yang berbentuk karya misalnya, karya seni, yang berupa gambar, patung, film, dan lain-lain.

\section{HASIL DAN PEMBAHASAN}

Hasil penelitian pengembangan yang telah dilaksanakan berupa asesmen biologi berbasis keterampilan proses sains. Hal-hal yang direncanakan pada tahap awal setelah menentukan kompetensi, peserta tes dan tujuan tes, yaitu membuat kisi-kisi, format pertanyaan atau jawaban, bentuk penyelenggaraan dan cara penskoran. Kisi-kisi soal asesmen berbasis keterampilan proses sains dapat dilihat pada Tabel 3. 
Jurnal Mangifera Edu, Volume 6, Issue 1, July 2021, 82-97

Tabel 3. Kisi-kisi soal asesmen berbasis keterampilan proses sains

\begin{tabular}{|c|c|c|c|c|}
\hline Kompetensi Dasar & Materi & $\begin{array}{c}\text { Indikator } \\
\text { Keterampilan } \\
\text { Proses Sains }\end{array}$ & $\begin{array}{c}\text { Nomor } \\
\text { Soal }\end{array}$ & $\begin{array}{c}\text { Kunci } \\
\text { Jawaban }\end{array}$ \\
\hline $\begin{array}{l}\text { 3.7 Menerapkan } \\
\text { prinsip Klasifikasi } \\
\text { untuk } \\
\text { menggolongkan } \\
\text { jamur berdasarkan } \\
\text { ciri-ciri, cara } \\
\text { reproduksi, dan } \\
\text { mengaitkan } \\
\text { peranannya dalam } \\
\text { kehidupan }\end{array}$ & $\begin{array}{l}\text { Fungi/Jamur } \\
\text { - Ciri-ciri kelompok } \\
\text { jamur : morfologi, cara } \\
\text { memperoleh nutrisi, } \\
\text { reproduksi } \\
\text { - Pengelompokan jamur } \\
\text { - Peran jamur dalam } \\
\text { bidang ekologi, } \\
\text { ekonomi, kesehatan, } \\
\text { dan pengembangan } \\
\text { iptek }\end{array}$ & $\begin{array}{l}\text { Mengamati } \\
\text { Klasifikasi } \\
\text { Menafsirkan } \\
\text { Meramalkan } \\
\text { Mengajukan } \\
\text { Pertanyaan } \\
\text { Berhipotesis } \\
\text { Merencanakan } \\
\text { Percobaan } \\
\text { Menerapkan } \\
\text { Konsep } \\
\text { Berkomunikasi }\end{array}$ & $\begin{array}{c}1 \\
2 \\
3 \\
4 \\
5 \\
6 \\
7 \\
8 \\
9 \\
10\end{array}$ & $\begin{array}{l}\text { D } \\
\text { B } \\
\text { B } \\
\text { A } \\
\text { A } \\
\text { A } \\
\text { C } \\
\text { B } \\
\text { A } \\
\text { C }\end{array}$ \\
\hline
\end{tabular}

\begin{tabular}{|c|c|c|c|c|}
\hline $\begin{array}{l}\text { 3.8 Menerapkan } \\
\text { prinsip Klasifikasi } \\
\text { untuk } \\
\text { menggolongkan } \\
\text { tumbuhan ke dalam } \\
\text { divisio berdasarkan } \\
\text { pengammatan dan } \\
\text { metagenesis tubuhan } \\
\text { serta mengaitkan } \\
\text { peranannya dalam } \\
\text { kelangsungan } \\
\text { kehidupan di bumi }\end{array}$ & $\begin{array}{l}\text { Plantae } \\
\text { - Ciri-ciri umum plantae: } \\
\text { tumbuhan lumut, } \\
\text { tumbuhan paku, } \\
\text { tumbuhan biji } \\
\text { - Peran tumbuhan dalam } \\
\text { ekosistem } \\
\text { - Peran tumbuhan di } \\
\text { bidang ekonomi } \\
\text { - Dampak berkurangnya } \\
\text { keanekaragaman } \\
\text { tumbuhan bagi } \\
\text { ekosistem }\end{array}$ & $\begin{array}{l}\text { Mengamati } \\
\text { Klasifikasi } \\
\text { Menafsirkan } \\
\text { Meramalkan } \\
\text { Mengajukan } \\
\text { Pertanyaan } \\
\text { Berhipotesis } \\
\text { Merencanakan } \\
\text { Percobaan } \\
\text { Menerapkan } \\
\text { Konsep } \\
\text { Berkomunikasi }\end{array}$ & $\begin{array}{l}11 \\
12 \\
13 \\
14 \\
15 \\
16 \\
17 \\
18 \\
19 \\
20 \\
21\end{array}$ & $\begin{array}{l}\text { B } \\
\text { D } \\
\text { E } \\
\text { A } \\
\text { B } \\
\text { A } \\
\text { D } \\
\text { D } \\
\text { A } \\
\text { A } \\
\text { B }\end{array}$ \\
\hline $\begin{array}{l}\text { 3.9 Menerapkan } \\
\text { prinsip Klasifikasi } \\
\text { untuk } \\
\text { menggolongkan } \\
\text { hewan ke dalam } \\
\text { filum berdasarkan } \\
\text { bentuk tubuh, } \\
\text { simetri tubuh, } \\
\text { rongga tubuh dan } \\
\text { reproduksi }\end{array}$ & $\begin{array}{l}\text { Animalia } \\
\text { - Ciri-ciri umum hewan } \\
\text { invertebrata (lapisan } \\
\text { tubuh, rongga tubuh, } \\
\text { simetri tubuh, dan } \\
\text { reproduksi) } \\
\text { - Ciri-ciri umum hewan } \\
\text { vertebrata (rangka } \\
\text { tubuh, ruang jantung, } \\
\text { reproduksi, suhu tubuh, } \\
\text { dan penutup tubuh) } \\
\text { - Klasifikasi animalia } \\
\text { Peran hewan bagi } \\
\text { kehidupan }\end{array}$ & $\begin{array}{l}\text { Mengamati } \\
\text { Klasifikasi } \\
\text { Menafsirkan } \\
\text { Meramalkan } \\
\text { Mengajukan } \\
\text { Pertanyaan } \\
\text { Berhipotesis } \\
\text { Merencanakan } \\
\text { Percobaan } \\
\text { Menerapkan } \\
\text { Konsep } \\
\text { Berkomunikasi }\end{array}$ & $\begin{array}{l}22 \\
23 \\
24 \\
25 \\
26 \\
27 \\
28 \\
29 \\
30 \\
31\end{array}$ & $\begin{array}{l}\text { A } \\
\text { D } \\
\text { B } \\
\text { B } \\
\text { B } \\
\text { D } \\
\text { D } \\
\text { A } \\
\text { B } \\
\text { B }\end{array}$ \\
\hline $\begin{array}{l}\text { 3.10 Menganalisis } \\
\text { informasi atau data } \\
\text { dari berbagai sumber } \\
\text { tentang ekosistem } \\
\text { dan semua interaksi }\end{array}$ & $\begin{array}{l}\text { Ekologi } \\
\text { - Komponen ekosistem } \\
\text { - Aliran energi } \\
\text { - Daur biogeokimia }\end{array}$ & $\begin{array}{l}\text { Mengamati } \\
\text { Klasifikasi } \\
\text { Menafsirkan } \\
\text { Meramalkan } \\
\text { Mengajukan }\end{array}$ & $\begin{array}{l}32 \\
33 \\
34 \\
35 \\
36\end{array}$ & $\begin{array}{l}\text { C } \\
\text { C } \\
\text { D } \\
\text { C } \\
\text { B }\end{array}$ \\
\hline
\end{tabular}


Jurnal Mangifera Edu, Volume 6, Issue 1, July 2021, 82-97

\begin{tabular}{|c|c|c|c|c|}
\hline $\begin{array}{l}\text { yang berlangsung di } \\
\text { dalamnya }\end{array}$ & $\begin{array}{l}\text { - Interaksi dalam } \\
\text { ekosistem }\end{array}$ & $\begin{array}{l}\text { Pertanyaan } \\
\text { Berhipotesis } \\
\text { Merencanakan } \\
\text { Percobaan } \\
\text { Menerapkan } \\
\text { Konsep } \\
\text { Berkomunikasi }\end{array}$ & $\begin{array}{l}37 \\
38 \\
39 \\
40\end{array}$ & $\begin{array}{l}\mathrm{B} \\
\mathrm{C} \\
\mathrm{A} \\
\mathrm{C}\end{array}$ \\
\hline $\begin{array}{l}\text { 3.11 Menganalisis } \\
\text { data perubahan } \\
\text { lingkungan dan } \\
\text { penyebab, serta } \\
\text { dampak dari } \\
\text { perubaha-perubahan } \\
\text { tersebut bagi } \\
\text { kehidupan }\end{array}$ & $\begin{array}{l}\text { Perubahan Lingkungan } \\
\text { - Kerusakan } \\
\text { lingkungan/pencemaran } \\
\text { lingkungan. } \\
\text { - Pelestarian lingkungan } \\
\text { - Adapatasi dan mitigasi } \\
\text { Limbah dan Daur Ulang } \\
\text { - Jenis-jenis limbah. } \\
\text { - Proses daur ulang } \\
\text { - } 3 \mathrm{R} \text { (reuse, reduse, } \\
\text { recycle) }\end{array}$ & $\begin{array}{l}\text { Mengamati } \\
\text { Klasifikasi } \\
\text { Menafsirkan } \\
\text { Meramalkan } \\
\text { Mengajukan } \\
\text { Pertanyaan } \\
\text { Berhipotesis } \\
\text { Merencanakan } \\
\text { Percobaan } \\
\text { Menerapkan } \\
\text { Konsep } \\
\text { Berkomunikasi }\end{array}$ & $\begin{array}{l}41 \\
42 \\
43 \\
44 \\
45 \\
46 \\
47 \\
48 \\
49 \\
50\end{array}$ & $\begin{array}{l}\text { C } \\
\text { E } \\
\text { A } \\
\text { B } \\
\text { B } \\
\text { D } \\
\text { D } \\
\text { A } \\
\text { A } \\
\text { C }\end{array}$ \\
\hline
\end{tabular}

Tabel 4. Persentase rata-rata soal keterampilan proses sains pada materi biologi di SMA Kota Palembang

\begin{tabular}{|c|c|c|c|c|c|c|c|}
\hline \multirow[b]{2}{*}{ No. } & \multirow[b]{2}{*}{$\begin{array}{l}\text { Keterampilan } \\
\text { Proses Sains } \\
\text { (KPS) }\end{array}$} & \multicolumn{4}{|c|}{ Nama Sekolah } & \multirow[b]{2}{*}{$\begin{array}{c}\text { Rata- } \\
\text { rata }\end{array}$} & \multirow[b]{2}{*}{ Kategori } \\
\hline & & $\begin{array}{c}\text { SMA Negeri } \\
19 \\
\text { Palembang } \\
\end{array}$ & $\begin{array}{c}\text { SMA } \\
\text { PGRI 2 } \\
\text { Palembang } \\
\end{array}$ & $\begin{array}{c}\text { SMA } \\
\text { Sriguna } \\
\text { Palembang } \\
\end{array}$ & $\begin{array}{c}\text { SMA } \\
\text { Negeri } 8 \\
\text { Palembang } \\
\end{array}$ & & \\
\hline 1. & $\begin{array}{l}\text { Mengamati/ } \\
\text { Mengobservasi } \\
(\%)\end{array}$ & 2,80 & 2,50 & 5 & 15 & 6,32 & Kurang \\
\hline 2. & $\begin{array}{l}\text { Mengelompokkan } \\
\text { / } \\
\text { Klasifikasi }(\%)\end{array}$ & 17,10 & 5 & 12,50 & 37,50 & 18,02 & Kurang \\
\hline 3. & $\begin{array}{l}\text { Menafsirkan/ } \\
\text { Interpretasi (\%) }\end{array}$ & 0 & 0 & 0 & 0 & 0 & Kurang \\
\hline 4. & $\begin{array}{l}\text { Meramalkan/ } \\
\text { Prediksi (\%) }\end{array}$ & 0 & 0 & 7,5 & 7,50 & 3,75 & Kurang \\
\hline 5. & $\begin{array}{l}\text { Mengajukan } \\
\text { Pertanyaan (\%) }\end{array}$ & 0 & 0 & 0 & 0 & 0 & Kurang \\
\hline 6. & $\begin{array}{l}\text { Berhipotesis (\%) } \\
\text { Merencanakan }\end{array}$ & 0 & 0 & 0 & 0 & 0 & Kurang \\
\hline 7. & $\begin{array}{l}\text { Percobaan/ } \\
\text { Penelitian }(\%)\end{array}$ & 0 & 2,50 & 0 & 7,50 & 2,50 & Kurang \\
\hline 8. & $\begin{array}{l}\text { Menerapkankonse } \\
\text { p (\%) }\end{array}$ & 0 & 0 & 0 & 0 & 0 & Kurang \\
\hline 9. & $\begin{array}{l}\text { Berkomunikasi } \\
(\%)\end{array}$ & 0 & 0 & 0 & 0 & 0 & Kurang \\
\hline & Jumlah & 19,90 & 10 & 25 & 67,50 & 29,35 & \\
\hline & Rata-rata & 2.21 & 1,11 & 2,77 & 7,50 & 3,26 & \\
\hline
\end{tabular}


Jurnal Mangifera Edu, Volume 6, Issue 1, July 2021, 82-97

Tabel 5. Hasil rata-rata penilaian validasi

\begin{tabular}{ccccc}
\hline No & Aspek yang Dinilai & $\begin{array}{c}\text { Persentase Skor } \\
\text { Rata-rata }(\%)\end{array}$ & Kualifikasi & Kategori \\
\hline 1. & Aspek Materi & 87,5 & Sangat Valid & $\begin{array}{c}\text { Tidak perlu } \\
\text { direvisi } \\
\text { Tidak perlu } \\
\text { direvisi } \\
\text { 2. }\end{array}$ \\
Aspek Bahasa & 75 & Valid & $\begin{array}{c}\text { Tidak perlu } \\
\text { direvisi }\end{array}$ \\
\hline
\end{tabular}

Hasil validasi dari dosen pembimbing yang sudah diperbaiki, kemudian dilakukan validasi oleh beberapa validator ahli materi validator ahli bahasa validator ahli evaluasi masing-masing validasi didapatkan hasil presentase keidealan dengan kategori ideal secara berturut-turut adalah 87,5\% (sangat valid), 75\% (valid) dan 84,3\% (sangat valid) tidak perlu direvisi. Artinya soal yang telah dibuat dapat dikatakan sangat layak sudah sesuai dengan jenjang yang menjadi objek sasaran pengembang.

Ada beberapa saran dan masukan untuk diperbaiki seperti instrumen sudah baik, dalam materi indikator yang digunakan harus berbeda pada skor membuat soal klasifikasi, meramalkan, berhipotesis dan menyesuaikan tahap pembelajaran dengan indikator keterampilan proses sains. Konsistensi penyusunan kalimat dan sistematik penulis secara umum ketuntasan dan pemakaian bahasa indonesia sudah baik dan benar. Terdapat kesalahan kalimat dan penyusunan kata tidak tepat, kalimat bertetele-tele bahwa harus memenuhi syarat-syarat kelengkapan kalimat, mengungkapkan gagasan yang jelas agar memudahkan peserta didik dalam memahami tulisan.

Membuat soal yang lebih variatif dan sesuaikan dengan indikator keterampilan proses sains, soal masih belum sesuai dengan aspek mengamati, hendaknya soal meminta siswa untuk mengamati struktur, morfologi, anatomi dan diminta untuk menjelaskan. Semua saran dan masukan sudah diperbaiki oleh peneliti dan dilanjutkan membuat petunjuk penyelenggara tes yang terdiri dari petunjuk untuk penyelenggara, pengawas ujian dan petunjuk untuk peserta tesitu sendiri.

\section{Karakteristik Asesmen Biologi Berbasis Keterampilan Proses Sains}

Asesmen yang di kembangkan dalam penelitian ini adalah soal pilihan ganda. Tujuan dari penggunaan tes ini untuk mengukur keterampilan proses sains peserta didik kelas X pada materi Jamur (Fungi), Dunia Tumbuhan (Plantae), Dunia Hewan (Animalia), Komponen Ekosistem, Pencemaran dan Pelestarian Lingkungan Hidup. Dalam kisi-kisi https://jurnal.biounwir.ac.id/index.php/mangiferaedu | 91 
yang dikembangkan menyesuaikan indikator dengan soal, instrumen tes berupa 50 soal pilihan ganda. Desain produk harus diwujudkan dalam gambar atau bagan, sehingga dapat digunakan sebagai pegangan atau menilai. Uji kelayakan perlu ditelaah secara kuantitatif oleh para ahli dengan menggunakan soal keterampilan proses sains yang telah dikembangkan dan angket yang dirancang. Lembar validasi sudah divalidasi oleh dosen ahli sebelum digunakan. Soal divalidasi oleh ahli meliputi intrumen validasi untuk menguji aspek kesesuian materi,bahasa dan evaluasi.

Karakteristik asesmen yang dikembangkan berbeda pada soal-soal yang digunakan di sekolah. Terkait hasil analisis kebutuhan awal, guru belum mengembangkan instrumen/asesmen berbasis keterampilan proses sains karena masih mengambil soal-soal dari buku biologi belum mengembangkan soal-soal berbasis keterampilan proses sains yang sesuai dengan indikator-indikator terdapat pada keterampilan proses sains. penilaian yang digunakan oleh guru juga masih mengacu pada aspek kognitif belum menerapkan soal-soal berbasis keterampilan proses sains. Soal keterampilan proses sains ini memiliki karakteristik pada soal-soal mampu memenuhi persyaratan-persyaratan yang dikatakan sebagai keterampilan proses sains, telah mencakup indikator-indikator keterampilan proses sains yang terdiri mengamati, klasifikasi, menafsirkan, meramalkan, mengajukan pertanyaan, berhipotesis, merencanakan percobaan, menggunakan alat, menerapkan konsep dan berkomunikasi.

Jadi, perlu dikembangkan soal keterampilang proses sains. Asesmen yang dikembangkan dapat menjadi variasi belajar bagi peserta didik, menuntut peserta dalam mengerjakan soal berbasis keterampilan proses sains dan bagi guru mata pelajaran sebagai pendukung dalam evaluasi pembelajaran.

Menurut pendapat Rimtha (2020), Penilaian keterampilan proses sains memiliki beberapa kelebihan yaitu menjelaskan deskripsi tugas, memberikan informasi bobot penilaian, penilaian lebih objektif dan konsisten, dan rubrik dapat diandalkan oleh guru untuk mengukur keterampilan proses sains peserta didik yang selama ini hanya menggunakan instrumen lembar kerja peserta didik tanpa memiliki tolak ukur penilaian.

Pentingnya keterampilan proses sains mengetahui sains tidak hanya sekedar mengetahui materi tentang sains saja tetapi terkait dengan memahami bagaimana cara untuk mengumpulkan fakta-fakta untuk membuat suatu penafsiran atau kesimpulan. Manfaat asesmen berbasis keterampilan proses sains bagi peserta didik diharapkan dapat melatih, 
Jurnal Mangifera Edu, Volume 6, Issue 1, July 2021, 82-97

mengukur, mengembangkan kemampuan keterampilan proses sains siswa, juga melahirkan peserta didik yang menguasai ilmu pengetahuan dan teknologi. Hal ini sesuai dengan pendapat Subali (2012), agar dapat diperoleh alat ukur yang baik perlu dikembangkan suatu prosedur atau langkah-langkah yang benar yang meliputi perencanaan asesmen yang memuat maksud dan tujuan asesmen yaitu, penyusunan kisi-kisi, penyusunan instrumen, penelaah (review) untuk menilai kualitas.

\section{Kelayakan Asesmen Biologi Berbasis Keterampilan Proses Sains}

Kelayakan pengembangan soal berbasis keterampilan proses sains di uji melalui tahapan expert judgment validity yang dilakukan oleh dosen ahli yang terdiri dari 2 orang validator ahli materi, 2 orang validator ahli bahasa dan 2 orang validator ahli evaluasi. Berdasarkan hasil analisis penilaian validator ahli materi yaitu dengan total rata-rata $87,5 \%$ dengan kategori sangat valid. Soal yang dikembangkan dapat dikatakan baik dan valid karena sudah sesuai dengan jenjang yang menjadi objek sasaran pengembang. Karena item sesuai dengan indikator keterampilan proses sains, hanya ada satu kunci atau jawaban yang benar, isi materi sesuai dengan tujuan pengukuran. Menyajikan materi pada soal yang dibuat sudah sangat baik agar tidak menimbulkan kebingungan bagi peserta didik dalam membaca. Penyajian soal, gambar/ilustrasi disajikan dengan jelas sehingga mampu memotivasi peserta didik untuk mempelajari soal yang telah disajikan. Untuk memunculkan motivasi peserta didik dapat pula mencantumkan penjelasan-penjelasan yang logis mengenai soal yang telah dikembangkan.

Validator ahli materi memberi komentar pada prinsipnya instrumen sudah baik, dalam materi indikator yang digunakan harus berbeda pada skor membuat soal mengelompokkan, meramalkan, berhipotesis dan menyesuaikan tahap pembelajaran dengan indikator keterampilan proses sains. Setelah dilakukan perbaikan soal, pada indikator mengelompokkan sudah sesuai dengan materi yang terkait dengan mengelompokkan jenisjenis jamur yang dimanfaatkan sebagai makanan. Indikator meramalkan sudah sesuai dengan materi yang terkait ingin mengetahui pertumbuhan tanaman tomat menggunakan insektisida dengan frekuensi 1 sampai 2 kali seminggu

Menurut pendapat Akbar (2020), dapat diketahui dalam membuat soal pilihan ganda sesuai dengan materi yang diberikan, pemahaman tersebut dirumuskan menjadi indikator, sehingga soal pilihan ganda yang dibuat sesuai dengan apa yang ada dalam indikator. 
Indikator merupakan penghubung dalam kegiatan evaluasi agar dapat mengukur secara akurat tingkat pemahaman peserta didik mengenai materi yang telah diberikan.

Menurut penilaian ahli validator asesmen dikatakan layak karena isi materi sesuai dengan tujuan dan indikator, gambar yang disajikan sesuai dengan penjelesan soal kemudian soal memiliki jawaban yang singkron dengan materi dan materi diambil dengan sumber yang jelas. Sesuai dengan pendapat Firdaus et al. (2014), Kelayakan materi menurut ahli yaitu kesesuaian uraian materi dengan kompetensi inti (KI) dan kompetensi dasar (KD) yang terdapat dalam kurikulum mata pelajaran yang bersangkutan, keakuratan materi dan materi pendukung pembelajaran.

Berdasarkan hasil validasi oleh ahli bahasa memperoleh presentase rata-rata $75 \%$ dengan kategori valid. Soal yang dikembangkan dapat dikatakan valid karena sudah sesuai dengan jenjang yang menjadi objek sasaran pengembang. Artinya asesmen yang telah dikembangkan sudah sesuai dengan syarat-syarat kaidah bahasa indonesia yang baik dan benar sehingga ahli validator memberikan nilai yang baik. Hal ini sesuai dengan pendapat BNSP (2014), yang menyatakan pada penggunaan bahasa untuk menjelaskan konsep atau aplikasi konsep atau wacana, teks, gambar dan ilustrasi sampai dengan contoh yang abstrak sesuai dengan tingkat intelektual peserta didik (yang secara imajinatif dapat dibayangkan oleh peserta didik).

Menurut penilaian ahli validator asesmen dikatakan layak karena konsistensi penyusunan kalimat dan sistematik penulis secara umum ketuntasan dan pemakaian bahasa indonesia sudah baik dan benar pada soal yang telah dibuat, rumusan kalimat tidak menimbulkan penafsiran ganda atau salah pengertian. Sesuai dengan pendapat Kartika et al. (2015), kelayakan bahasa meliputi komunikatif, dialogis dan interatif, lugas, keruntutan alur pikir, koherensi, kesesuaian dengan kaidah bahasa indonesia yang benar, dan penggunaan istilah dan simbol atau lambang yang sesuai dengan perkembangan peserta didik.

Validator bahasa memberi komentar konsistensi penyusunan kalimat dan sistematik penulis secara umum ketuntasan dan pemakaian bahasa indonesia sudah baik dan benar. Tulisan yang saya buat terdapat kesalahan kalimatnya dan penyusunan kata tidak tepat, kalimat bertetele-tele bahwa harus memenuhi syarat kelengkapan kalimat, mengungkapkan gagasan yang jelas agar memudahkan peserta didik dalam memahami tulisan. Sehingga sudah dilakukan perbaikan soal yang dibuat menggunakan bahasa indonesia sesuai dengan kaidah, menggunakan bahasa yang komunikatif dan mudah dimengerti, tidak mengandung 
bahasa yang ambigu, selaras dengan edisi terbaru berdasarkan peraturan Menteri Pendidikan dan Kebudayaan RI No. 50/ 2015 tanggal 26 November 2015, tentang Pedoman Umum Ejaan Bahasa Indonesia (PUEBI) yang di dalamnya tercantum pemakaian huruf, penulisan kata dan pemakaian tanda baca yang baik dan benar.

Berdasarkan hasil validasi oleh ahli evaluasi memperoleh presentase rata-rata $84,3 \%$ dengan kategori sangat valid. Asesmen berbasis keterampilan proses sains yang telah dikembangkan dapat dikatakan sangat valid sudah sesuai dengan jenjang yang menjadi objek sasaran pengembang. Karena asesmen yang telah dibuat sudah mencakup indikator pencapaian kompetensi dan indikator keterampilan proses sains. Validator evaluasi memberi komentar dalam membuat soal yang lebih variatif dan sesuaikan dengan indikator keterampilan proses sains, soal masih belum sesuai dengan aspek mengamati, hendaknya soal meminta siswa untuk mengamati struktur, morfologi, anatomi dan diminta untuk menjelaskan. Soal yang telah direvisi sudah dilakukan perbaikan pada setiap soal yang dikembangkan menyesuaikan indikator keterampilan proses sains dengan KD dan KI.

Hal ini sesuai dengan pendapat Ayuni (2015), tingkat pemahaman pada indikator mengamati yang tergolong cukup perlu ditingkatkan agar menjadi lebih baik lagi, agar dalam pelaksanaanya dapat memperoleh hasil yang memuaskan. Lingkungan sebagai sumber belajar sangat bermanfaat bagi guru maupun peserta didik, karena dapat melihat langsung di lapangan, melihat langsung fakta yang ada.

Menurut penilaian ahli validator asesmen dikatakan layak karena antar item tidak bergantung satu sama lain soal yang dibuat bervariasi, dan sesuai dengan indikator keterampilan proses sains. Kesuaian indikator bertujuan untuk mempermudah dalam membedakan soal-soal yang telah dibuat. Sesuai dengan pendapat Wardany \& Anjarwati (2020), instrumen evaluasi untuk memvalidasi kesusuaikan soal dengan indikator (validitas konstruk) sehingga menjamin soal yang dikembangkan dapat mengukur peserta didik.

\section{SIMPULAN}

Karakteristik soal yang dikembangkan telah mencakup indikator-indikator keterampilan proses sains yang terdiri atas mengamati, klasifikasi, menafsirkan, meramalkan, mengajukan pertanyaan, berhioptesis, merencanakan percobaan, menerapkan konsep dan berkomunikasi. Asesmen biologi berbasis keterampilan proses sains dinyatakan layak berdasarkan hasil validator ahli materi berkualifikasi sangat valid, ahli bahasa 
Jurnal Mangifera Edu, Volume 6, Issue 1, July 2021, 82-97

berkualifikasi baik dan ahli evaluasi berkualifikasi sangat valid, jadi dapat di simpulkan bahwa asesmen biologi berbasis keterampilan proses sains yang dikembangkan layak untuk digunakan.

\section{DAFTAR PUSTAKA}

Aseptianova, A., Nawawi, S., \& Yuliandina, M. (2019). Pengembangan Asesmen Biologi Berbasis Keterampilan Berpikir Kritis Siswa Kelas XI Semester Genap di SMA Muhammadiyah 1 Palembang. Bioedukasi, 10(1), 1-13.

Akbar, A. (2020). Kemampuan Mahasiswa Dalam Penyusunan Soal Pilihan Ganda. Attadib Journal Of Elementary Education, 4(1), 44-53.

Ayuni, F. N. (2015). Pemahaman Guru Terhadap Pendekatan Saintifik (Scientific Approach) dalam Pembelajaran Geografi. Pendidikan Geografi, 15(2), 1-7.

BSNP. 2014. Instrumen Penilaian Buku Teks Pelajaran Tahun 2014. Jakarta: BSNP.

Firdaus, A., Samhati, S., \& Suyanto, E. (2014). Analisis Kelayakan Isi Buku Teks Bahasa Indonesia Terbitan Erlangga Kelas VII SMP/MTs. Jurnal Kata (Bahasa, Sastra, dan Pembelajarannya), 1-12.

Husnita, L., Wardhani, S., \& Nawawi, S. (2019). Analisis Tingkat Keterampilan Berpikir Kritis Siswa pada Materi Sel di SMA Negeri Palembang. Bioilmi, 5(2), 114-126.

Kartikasari, Y., Widodo, M., \& Karomani. (2015). Kelayakan Isi dan Bahasa pada Buku Teks Bupena Bahasa Indonesia Kelas VII. Jurnal Kata (Bahasa, Sastra, dan Pembelajarannya), 1-6.

Mulyatiningsih, E. (2011). Riset Terapan Bidang Pendidikan\&Teknik. Yogyakarta: UNY Press.

Rustaman, dkk. (2012). Materi dan Pembelajaran IPA SD. Tanggeran Selatan : Universitas Terbuka.

Riduwan, M. (2015). Pengembangan Media Pembelajaran Visual Basic Untuk Mengajar Teknik Pemrograman di kelas X Teknik Elektronika SMK Negeri 1 Sidoarjo. Jurnal Pendidikan Teknik Elektro, 4(3), 863-868.

Subali, B. (2012). Penilaian Evaluasi dan Rediasi Pembelajaran Biologi. Yogyakarta: UNY.

Sugiyono. (2018). Metode Penelitian Pendidikan (Pendekatan Kauntitatif, Kualitatif, dan $R \& D)$. Bandung: Alfabeta. 
Tim Penyusun. (2015). Pedoman Umum Ejaan Bahasa Indonesia. Jakarta: Badan Pengembangan dan Pembinaan Bahasa.

Wijayanti, A. (2014). Pengembang Autentic Assesment Berbasis Proyek dengan Pendekatan Saintifik Untuk Meningkatkan Keterampilan Berpikir Ilmiah Mahasiswa. Pendidikan IPA Indonesia, 3(2), 102-108.

Wijaya, E. Y., Sudjimat, D. A., \& Nyoto, A. (2016). Transformasi Pendidikan Abad 21 Sebagai Tuntutan Pengembangan Sumber Daya Manusia di Era Global. Prosiding Seminar Nasional Pendidikan Matematika, 1(26), 263-278.

Wardany, K., \& Anjarwati, S. (2020). Kelayakan Instrumen Penilaian Higher Order Thinking Skills pada Materi Lingkungan. Indonesian Science Education Journal, 1(3), 226-237. 